\title{
Microbial nutrient limitation in Arctic lakes in a permafrost landscape of southwest Greenland
}

\author{
B. Burpee ${ }^{1}$, J. E. Saros ${ }^{1}$, R. M. Northington ${ }^{1}$, and K. S. Simon ${ }^{2}$ \\ ${ }^{1}$ Climate Change Institute, and School of Biology \& Ecology, University of Maine, Maine, USA \\ ${ }^{2}$ School of Environment, University of Auckland, Auckland, New Zealand \\ Correspondence to: B. Burpee (benjaminburpee@gmail.com)
}

Received: 29 June 2015 - Published in Biogeosciences Discuss.: 30 July 2015

Revised: 21 December 2015 - Accepted: 22 December 2015 - Published: 19 January 2016

\begin{abstract}
Permafrost is degrading across regions of the Arctic, which can lead to increases in nutrient concentrations in surface freshwaters. The oligotrophic state of many Arctic lakes suggests that enhanced nutrient inputs may have important effects on these systems, but little is known about microbial nutrient limitation patterns in these lakes. We investigated microbial extracellular enzyme activities (EEAs) to infer seasonal nutrient dynamics and limitation across 24 lakes in southwest Greenland during summer (June and July). From early to late summer, enzyme activities that indicate microbial carbon $(\mathrm{C})$, nitrogen $(\mathrm{N})$, and phosphorus $(\mathrm{P})$ demand increased in both the epilimnia and hypolimnia by $74 \%$ on average. Microbial investment in $\mathrm{P}$ acquisition was generally higher than that for N. Interactions among EEAs indicated that microbes were primarily P-limited. Dissolved organic matter (DOM, measured as dissolved organic carbon) was strongly and positively correlated with microbial $\mathrm{P}$ demand $\left(R^{2}=0.84\right.$ in July), while there were no relationships between DOM and microbial $\mathrm{N}$ demand. Microbial $\mathrm{P}$ limitation in June epilimnia $\left(R^{2}=0.67\right)$ and July hypolimnia $\left(R^{2}=0.57\right)$ increased with DOM concentration. The consistency of microbial P limitation from June to July was related to the amount of DOM present, with some low-DOM lakes becoming N-limited in July. Our results suggest that future changes in $\mathrm{P}$ or DOM inputs to these lakes are likely to alter microbial nutrient limitation patterns.
\end{abstract}

\section{Introduction}

Permafrost degradation is one of the most prominent responses of Arctic landscapes to accelerated warming. Many factors can influence the thaw rate of permafrost (Zhang et al., 2005; Jorgenson et al., 2010), but permafrost thaw is very sensitive to even small changes in air and ground temperatures (Hinkel and Nelson, 2003; Zhang et al., 2005; Romanovsky et al., 2007; White et al., 2007). Permafrost is expected to continue to degrade in response to climate warming (Jorgensen et al., 2001, 2006; Lawrence and Slater, 2005; Frey and McClelland, 2009), with some models predicting that in areas of continuous permafrost, near-surface permafrost extent will decrease by 26-90\% (Lawrence and Slater, 2005; Anisimov and Reneva, 2006) and soil activelayer depth will deepen by 30-100\% (Stendel and Christensen, 2002; Zhang et al., 2008) over the next century. Such changes are likely to alter biogeochemical cycling in soils and the aquatic systems that receive material from soils.

The soil active-layer controls much of the tundra landscape's hydrologic and biogeochemical activity (Hinzman et al., 1991; Waelbroeck et al., 1997; Zhang et al., 2005; Schuur et al., 2008; Frey and McClelland, 2009), which in turn affects groundwater and nutrient inputs to Arctic aquatic ecosystems (Hobbie et al., 1999; Zhang et al., 2005; White et al., 2007). Degradation of permafrost typically increases phosphorus (P) export to surface waters (Hobbie et al., 1999, Frey and McClelland, 2009), while changes in inorganic nitrogen $(\mathrm{N})$ and dissolved organic carbon (DOC) are less consistent. For example, with permafrost thaw, watershed DOC export in the Yukon, Alaska, and central Siberia decreased (Carey, 2003; Kawahigashi et al., 2004; Striegl et al., 2005; 
McClelland et al., 2007), whereas it increased in west Siberia (Frey and Smith, 2005).

These water chemistry changes are important for the ecology of Arctic lakes because they alter nutrient and energy availability to phytoplankton and heterotrophic microbes. Hobbie et al. (1999) demonstrated that permafrost thaw in northern Alaska contributed $30 \%$ of inflowing phosphate and nitrate into Toolik Lake. Long-term experimental manipulation of another lake at that study site demonstrated that sustained $\mathrm{P}$ inputs increased primary production and increased phytoplankton biomass (Hobbie et al., 1999). It was therefore speculated that $\mathrm{P}$ inputs from permafrost degradation would increase lake eutrophication. However, another experimental study on Alaskan Arctic lakes indicated that $\mathrm{N}$ subsidies may be more important than $\mathrm{P}$ in stimulating phytoplankton productivity (Levine and Whalen, 2001). Despite these few studies, the nature and magnitude of permafrost degradation effects on Arctic lakes remain largely uncharacterized and largely focused on phytoplankton production.

Heterotrophic bacteria are key to aquatic biogeochemical reactions and transformations, and they should be susceptible to changes in DOC and nutrient input to lakes in Arctic systems (Cotner and Biddanda, 2002; Villar-Argaiz et al., 2002; Crump et al., 2003). Due to microbial mineralization of $\mathrm{C}$, Arctic lakes can release significant amounts of greenhouse gases, such as $\mathrm{CO}_{2}$ and $\mathrm{CH}_{4}$ (Kling et al., 1992). In Arctic lakes, the source of DOM can shift seasonally from the landscape (allochthonous DOM) to in-lake production (autochthonous) (Whalen and Cornwell, 1985). This can shift microbial community structure and production rates (Crump et al., 2003). In aquatic systems receiving nutrient subsidies, nutrient limitation of bacteria should relax. This would increase the rate by which heterotrophic bacteria consume organic matter for growth and respiration, resulting in increased $\mathrm{CO}_{2}$ production in oxygenic environments, or $\mathrm{CH}_{4}$ in anoxic ones (del Giorgio and Cole, 1998; Smith and Prairie, 2004). This has important implications for Arctic lakes that may receive nutrient subsidies through permafrost degradation. For instance, microbial growth increased in lake and pond waters of the high Canadian Arctic that received experimental $\mathrm{P}$ subsidies, indicating microbial P limitation (Granéli et al., 2004). Alternatively, in lakes that receive fewer hydrological inputs of nutrients and DOM due to increased soil active-layer depth and catchment microbial activity, the size of DOM and nutrient pools would decrease. Such a decrease would initiate a simplification of lake microbial food web structure (Hobbie et al., 2000). Further investigating heterotrophic microbial activity in Arctic lakes at present is important to understanding future thaw-driven changes in nutrient inputs.

One way to assess the nutrient demands of microbial communities is to measure activities of extracellular enzymes (EEAs), used by microbes to cleave complex organic molecules into smaller compounds that can be assimilated. Relative activities of enzymes associated with C,
$\mathrm{N}$, and $\mathrm{P}$ acquisition can be used to infer nutrient limitation following resource allocation models (Sinsabaugh et al., 2008). Enzymes of interest in EEA studies commonly include $\beta$-1,4-glucosidase (BG), which degrades cellulose and $\beta$-1,4-glucans to glucose for $\mathrm{C}$ acquisition (Ljungdahl and Eriksson 1985; Sinsabaugh et al., 2008); $\beta-1,4-$ $\mathrm{N}$-acetylglucosaminidase (NAG) and leucine aminopeptidase (LAP), which acquire $\mathrm{N}$ from chitin and polypeptides, respectively (Sinsabaugh and Foreman, 2001; Sinsabaugh et al., 2008); and phosphatase (AP), which degrades phosphomonoesters to obtain P (Turner et al., 2002; Sinsabaugh et al., 2008). These enzymes are catalysts for terminal reactions in which organic matter is converted to monomer nutrients (Sinsabaugh et al., 2008). As such, their activity reflects total microbial demand for C (via BG), N (via NAG + LAP), and $\mathrm{P}$ (via AP). Recent work has established the use of EEAs as a method to infer microbial nutrient limitation (Sinsabaugh et al., 2008; Moorhead et al., 2013; Hill et al., 2014), making EEA assays an extremely valuable tool for evaluating changing nutrient concentrations in aquatic ecosystems.

We examined microbial nutrient limitation patterns, via EEA analysis, and water chemistry in lakes spanning a range of nutrient availability in the continuous permafrost landscape of southwest Greenland. While the Alaskan, Siberian, and Canadian Arctic have shown consistent increases in air temperatures and active-layer thickening since the mid-1970s (Blunden and Arndt, 2014), recent and abrupt $\left(>10^{\circ} \mathrm{C}\right.$ ) warming in western Greenland (Hanna et al., 2012) coincides with deepening permafrost active layer only since the mid-1990s (Christiansen et al., 2010). As a result, these relatively recent changes in Greenland provide a unique situation in which we could examine patterns in microbenutrient relationships in a landscape with relatively low permafrost loss, providing a baseline from which to gauge future change. We measured EEA during the summer of 2013 in 24 lakes situated around Kangerlussuaq, southwest Greenland. We hypothesized that most lakes would be P-limited based on previous findings with phytoplankton experiments in this area (Brutemark et al., 2006), but that patterns in microbial enzyme allocation toward $\mathrm{C}, \mathrm{N}$, and $\mathrm{P}$ would track variation in lake water DOC, dissolved inorganic N (DIN), and total P (TP) availability.

\section{Methods}

\subsection{Study site}

The region around Kangerlussuaq, Greenland $\left(67^{\circ} 00^{\prime} \mathrm{N}\right.$, $50^{\circ} 41^{\prime} \mathrm{W}$, Fig. 1), contains more than 20000 lakes (Anderson et al., 2001) and is underlain by continuous permafrost estimated to be $300 \mathrm{~m}$ thick (Nielson, 2010; Harper et al., 2011). The climate of this region is low Arctic continental with a mean summer temperature of $10.2^{\circ} \mathrm{C}$. In western Greenland, annual air temperature has increased by $3{ }^{\circ} \mathrm{C}$ and annual melting degree days by $100 \%$ when comparing 


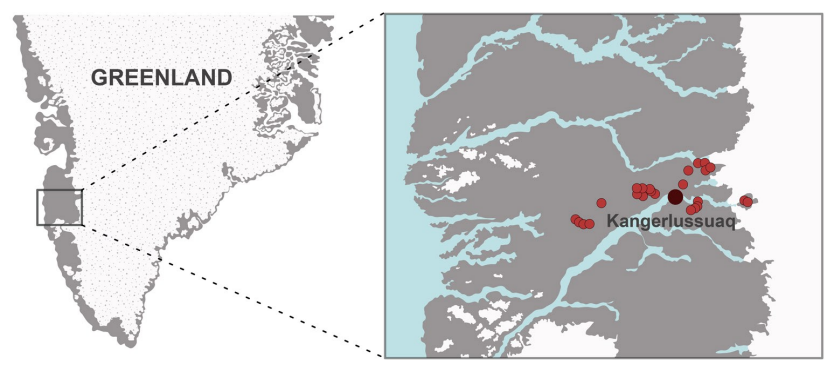

Figure 1. Map of study site, with the 24 study lakes surrounding Kangerlussuaq, Greenland, indicated by dots.

2007-2012 to 1979-2000 (Mayewski et al., 2014). The region is semiarid, receiving approximately $150 \mathrm{~mm}$ of precipitation per year and even less at the ice sheet margin. Lakes in this study ranged in surface area from 0.02 to $0.8 \mathrm{~km}^{2}$ and in maximum depth from 9 to $36 \mathrm{~m}$. Most of these lakes are oligotrophic, with low nutrient concentrations characteristic of lakes in this region (Anderson et al., 2001; Perren et al., 2009). Lakes were first sampled in June shortly following ice-off. At that time, about half of the study lakes were weakly stratified. For those that were not, the "hypolimnion" sample depth was the estimated limit of the euphotic zone determined as twice the measured Secchi depth. Lakes were sampled again in July, during the period of stable thermal stratification for all lakes.

\subsection{Environmental parameters}

Physical and chemical variables of the lakes were measured to determine their relationship to microbial EEAs within the epilimnia of the study lakes. Temperature and $\mathrm{pH}$ were measured at the point of greatest lake depth using a submersible HydroLab Datasonde 5a. Epilimnetic and hypolimnetic water samples were collected with a van Dorn bottle. Water samples for measurement of dissolved nutrients and DOC were filtered through Whatman GF/F filters that were prerinsed with DI water. Samples for total nutrients were unfiltered. All samples were collected into acid-washed bottles and kept refrigerated until analysis. Dissolved inorganic $\left(\mathrm{NH}_{4}^{+}, \mathrm{NO}_{3}^{-}\right.$, and $\left.\mathrm{PO}_{4}^{3-}\right)$ and total nutrient (TN and TP) concentrations were analyzed on a Lachat QuickChem 8500 flow injection analyzer. Nitrate was measured with the cadmium reduction method, $\mathrm{NH}_{4}^{+}$with the phenate method, and $\mathrm{PO}_{4}^{3-}$ with the ascorbic acid method (APHA, 2000). TN and TP were determined by measurement of $\mathrm{NO}_{3}^{-}$and $\mathrm{PO}_{4}^{3-}$ on unfiltered water samples following digestion with persulfate (APHA, 2000). Quantification limits on all nutrients were $2 \mu \mathrm{g} \mathrm{L}^{-1}$ except for TN, which was $10 \mu \mathrm{g} \mathrm{L}^{-1}$. For statistical analyses, nutrient values below the $2 \mu \mathrm{g} \mathrm{L}{ }^{-1}$ quantification limit were replaced with 1 . Dissolved inorganic nitrogen : TP (DIN : TP) ratios were calculated, with DIN determined by the addition of $\mathrm{NH}_{4}^{+}$and $\mathrm{NO}_{3}^{-}$. The DIN : TP ratio is a useful metric for inferring nutrient limitation, mov- ing from $\mathrm{N}$ to $\mathrm{P}$ limitation with an increase from 1.5 to 3.4 (Bergström, 2010). DOC was analyzed with an OI Analytical Aurora 1030D TOC analyzer using wet chemical oxidation.

\subsection{EEA analysis}

Water samples for EEA analysis were collected in the same way as total nutrient samples (i.e., not filtered). Due to the remote location of the lakes, samples from June were stored frozen $\left(-20^{\circ} \mathrm{C}\right)$ for 60 days and samples from July were refrigerated for 30 days and then frozen for 30 days before analysis. Though the analysis of fresh samples is considered preferable due to the uncertainty of whether freezing introduces bias into results, it is common for freshwater EEA studies to freeze samples owing to logistical constraints (e.g., Simon et al., 2009; Clinton et al., 2010; Freimann et al., 2013; Parr et al., 2015). We are assuming that if freezing had any effect it was similar across systems. EEA samples were thawed, processed, and analyzed with a Thermo Electron Corporation Fluoroskan Ascent FL fluorescence spectrophotometer using fluorescent-labeled substrates following published methods (Sinsabaugh and Foreman, 2001; Findlay et al., 2003). Fluorescent substrates were used to measure activity of BG (4-MUB- $\beta$-D-glucoside), NAG (4-MUB-Nacetyl- $\beta$-D-glucosaminide), LAP (L-Leucine-7-AMC), and AP (4-MUB-phosphate). Briefly, $200 \mu \mathrm{L}$ sub-samples from each lake sample were added in triplicate to 96 well assay plates and combined with $50 \mu \mathrm{L}$ of substrate for a final saturated substrate concentration of $200 \mu \mathrm{M}$ and assayed at $25^{\circ} \mathrm{C}$. Controls for substrate and sample fluorescence and quenching were included. Pilot assays were used to ensure substrate concentrations saturated enzyme kinetics such that kinetic rates were equal to $V_{\max }$, and readings were made during linear increases in fluorescence. Throughout the analysis, steps were taken to standardize and optimize the procedure following the suggestions of German et al. (2011).

\subsection{Data analysis}

Microbial nutrient limitation was inferred from activity of individual enzymes and from ratios of multiple enzymes. Across ecosystems, nutrient acquisition effort as measured by $\mathrm{BG}, \mathrm{NAG}+\mathrm{LAP}$, and AP is typically close to $1: 1: 1$ based on global empirical evidence and following stoichiometric and metabolic theories (Sinsabaugh et al., 2008, 2009). Departures from these values are indicative of differential microbial nutrient demand as microbes invest resources in enzymes to acquire limiting nutrients. The degree of $\mathrm{C}$ limitation can be inferred from ratios of $\mathrm{C}$ to nutrient-acquiring enzymes (BG : NAG + LAP and BG : AP; Sinsabaugh et al., 2008, 2009). Further, the stoichiometric ratios BG : NAG + LAP and BG : AP can be considered in concert to gauge degree of microbial $\mathrm{N}$ or $\mathrm{P}$ limitation (Moorhead et al., 2013; Hill et al., 2014). This can be done by plotting $\mathrm{BG}$ : NAG + LAP vs. BG: AP and measuring deviation 


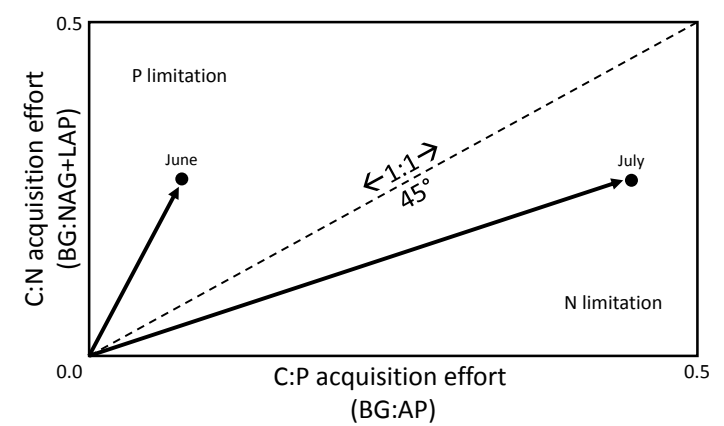

Figure 2. An example of vector plot analysis for a hypothetical lake sampled in June and July. The $1: 1$ line is drawn in dashes and separates zones of $\mathrm{P}$ imitation (above) from $\mathrm{N}$ limitation (below). Vectors for each data point are drawn in arrows. Their angles indicate microbial nutrient limitation, such that the positive angle value with respect to the $1: 1$ line in June indicates $P$ limitation, while the negative one in July indicates a shift to $\mathrm{N}$ limitation. The lengths of the vectors are also indicative of microbial $\mathrm{C}$ acquisition efforts, which in this example are greater in July than in June.

from the $1: 1$ line, which indicates equal nutrient acquisition effort (Sinsabaugh et al., 2008, 2009; Moorhead et al., 2013; Hill et al., 2014). On these plots the distance from the origin to a data point forms a vector. Deviation of the vector angle from the $1: 1\left(45^{\circ}\right)$ line indicates increasing $\mathrm{P}$ (higher angles) or N (lower angles) limitation (Moorhead et al., 2013; Hill et al., 2014). Figure 2 displays hypothetical data from a lake in June and July plotted onto a vector plot with the $1: 1$ line drawn in dashes. The vectors from which angles are calculated are shown as arrows from the origin to the individual data points. In June, the vector angle is positive with respect to the 1:1 line $\left(>45^{\circ}\right)$, indicating $\mathrm{P}$ limitation in this lake. However, in July nutrient limitation shifts from $\mathrm{P}$ to $\mathrm{N}$, as indicated by the negative angle with respect to the $1: 1$ line $\left(<45^{\circ}\right)$. We quantified vector angles for our samples and display the data as degrees of deviation from the $1: 1$ line such that positive values indicate $\mathrm{P}$ limitation and negative ones indicate $\mathrm{N}$ limitation (Fig. 5). Lastly, the distance of data points from the origin indicates microbial investment in $\mathrm{C}$ acquisition relative to that of $\mathrm{N}$ and $\mathrm{P}$, such that $\mathrm{C}$ demand is indicated by larger vector lengths (Moorhead et al., 2013, Hill et al., 2014).

To test whether water quality parameters, nutrient concentrations, or enzyme-related activities differed between months (June vs. July) or lake strata (epilimnia vs. hypolimnia), two-tailed, paired $t$ tests were used. To determine whether certain factors, such as nutrient concentrations or ratios, were related to enzyme activities, simple least-squares linear regression was used with a level of significance of $p=0.05$. All statistical analyses were completed using $\mathrm{R}$ (version 3.1.2).

\section{Results}

\subsection{Water quality parameters}

Several physical and chemical parameters varied from June to July in lake epilimnia (Table 1; Table S1 in the Supplement). Surface water temperatures increased between June and July, on average from 7.8 to $13.5^{\circ} \mathrm{C}(p<0.01)$. $\mathrm{pH}$ was relatively consistent across lakes (5.8-7.7) but on average increased from 6.6 in June to 7.0 in July $(p<0.01)$. DOC ranged 10 -fold from 4 to $40 \mathrm{mg} \mathrm{L}^{-1}$ across study lakes, and it slightly increased, on average, over the summer (12.1 to $\left.13.4 \mathrm{mg} \mathrm{L}^{-1}, p<0.01\right)$. DIN ranged from 2 to $25 \mu \mathrm{g} \mathrm{L}^{-1}$, and increased from June to July (6 to $12 \mu \mathrm{g} \mathrm{L} \mathrm{L}^{-1}, p<0.01$ ), as $\operatorname{did} \mathrm{TN}$ (467 to $554 \mu \mathrm{g} \mathrm{L}{ }^{-1}, p<0.01$, range from 178 to $1132 \mu \mathrm{g} \mathrm{L}^{-1}$ ). TP ranged from <2 to $12 \mu \mathrm{g} \mathrm{L}^{-1}$ and did not appreciably increase from June to July ( 4 to $5 \mu \mathrm{g} \mathrm{L}^{-1}$, $p=0.68) . \mathrm{PO}_{4}^{3-}$ was below quantification limits at all times. DIN : TP ranged from 0.17 to 22 and increased from June to July $(2.1$ to $5.4, p<0.01)$. TN was tightly related to DOC in both months (June; $R^{2}=0.83, p<0.01$; July $R^{2}=0.77$ $p<0.01)$. There were no relationships between TP and DOC, or DIN : TP and DOC.

\subsection{Seasonal and spatial patterns in enzyme activities}

Activity of all enzymes increased from June to July in both the epilimnia ( $p$ values $\leq 0.03$ ) and hypolimnia ( $p$ values $\leq$ 0.02; Fig. 3). Averaged between lake strata, BG activity increased $73 \%$, NAG + LAP 79\%, and AP $70 \%$ from June to July. Averaged across lakes, absolute activities of single enzymes differed between epilimnetic and hypolimnetic samples. For BG, epilimnetic activities were 1.7 times higher than those of hypolimnia in June $(p=0.01)$ and 1.3 times higher in July $(p=0.42)$. For NAG + LAP, epilimnetic activities were 1.1 and 1.3 times higher than those of hypolimnia in June and July ( $p<0.01$ and $p=0.01$, respectively). There were no differences in AP activities between strata in either month ( $p$ values $>0.05$ ).

Ratios of $\mathrm{C}$ to nutrient-acquiring enzyme activity varied by lake strata and time (Fig. 4). Hypolimnetic BG : AP was consistently lower than epilimnetic BG: AP, though the difference was not significant in July (June $p=0.01$, July $p=0.09)$. In June, epilimnetic BG: NAG + LAP was greater than that of the hypolimnia $(p=0.03)$, but in July there was no difference $(p=0.72)$. There were no seasonal differences in $\mathrm{BG}: \mathrm{AP}$ or $\mathrm{BG}: \mathrm{NAG}+\mathrm{LAP}$ within the same stratum ( $p$ values $<0.05)$. BG : NAG + LAP was greater than BG: AP in epilimnia and hypolimnia in June ( $p$ values $<0.01$ ) but not in July ( $p$ values $>0.05$ ). These data suggest microbes were investing more in $\mathrm{P}$ and less in $\mathrm{N}$ acquisition across lakes in June but not July.

Vector angles were mostly positive, indicating consistent microbial P limitation across all lakes in both time periods (Fig. 5). In the epilimnia, the angle magnitude was about 3 
Table 1. Epilimnetic physical and chemical data across the 24 lakes in June and July 2013. Significant changes ( $p \leq 0.05)$ between June and July means are indicated by asterisk (*). Depth was not measured in July. SE: standard error.

\begin{tabular}{lcccccc}
\hline & \multicolumn{3}{c}{ June } & \multicolumn{3}{c}{ July } \\
& Mean & SE & Range & Mean & SE & Range \\
\hline Depth $(\mathrm{m})$ & 19.7 & 1.67 & $8-36$ & - & - & - \\
pH & 6.6 & 0.08 & $5.8-7.2$ & $7.0^{*}$ & 0.07 & $6.4-7.7$ \\
Temperature $\left({ }^{\circ} \mathrm{C}\right)$ & 7.8 & 0.40 & $5.3-11.6$ & $13.5^{*}$ & 0.35 & $9.1-17.4$ \\
DIN $\left(\mu \mathrm{g} \mathrm{L}^{-1}\right)$ & 6 & 1.2 & $2-25$ & $12^{*}$ & 1.1 & $4-22$ \\
TN $\left(\mu \mathrm{g} \mathrm{L}^{-1}\right)$ & 467 & 47 & $178-1042$ & $554^{*}$ & 61 & $197-1132$ \\
TP $\left(\mu \mathrm{g} \mathrm{L}^{-1}\right)$ & 4 & 0.7 & $<2-12$ & 5 & 0.7 & $<2-11$ \\
DOC $\left(\mathrm{mg} \mathrm{L}^{-1}\right)$ & 12 & 1.9 & $4-35$ & $13^{*}$ & 2.2 & $4-40$ \\
DIN : $\mathrm{TP}$ & 2.1 & 0.37 & $0.17-6.0$ & $5.4^{*}$ & 1.4 & $0.55-22$ \\
\hline
\end{tabular}

Table 2. Nutrient Limitation and $C$ acquisition as indicated by mean vector angle and length for both months. Significant changes ( $p \leq 0.05)$ between June and July means are indicated by asterisk (*). SE: standard error.

\begin{tabular}{llcccccc}
\hline & & \multicolumn{3}{c}{ June } & \multicolumn{3}{c}{ July } \\
& & Mean & SE & Range & Mean & SE & Range \\
\hline \multirow{2}{*}{ Epilimnia } & ${\text { Vector angle }\left(^{\circ}\right)}^{*} 16$ & 2.82 & -8 to 41 & $4^{*}$ & 5.52 & -32 to 41 \\
& Vector length $^{*}$ Hypolimnia & 8.9 & 1.75 & $1.6-40.2$ & 9.9 & 2.98 & $0.2-58.4$ \\
\hline \multirow{2}{*}{ Vector angle $\left({ }^{\circ}\right)$} & 20 & 3.08 & -6 to 45 & $15^{*}$ & 4.93 & -30 to 43 \\
& Vector length $^{*}$ & 4.7 & 1.10 & $0.2-24.8$ & 7.3 & 2.69 & $0.2-62.8$ \\
\hline
\end{tabular}

times lower in July than in June, suggesting relaxed P limitation later in the year $(p<0.01$, Table 2$)$. This was less obvious in the hypolimnia where June and July data were much more similar $(p=0.04)$. Angles in the hypolimnia were 1.3 times greater than those of the epilimnia in June and 3.6 times greater in July ( $p$ values $<0.01$ ). On the vector plots, distance of data points from the origin did not change between June and July within the same strata (Table 2). This indicates that microbial investment in $\mathrm{C}$ acquisition did not appreciably vary with respect to $\mathrm{N}$ - and P-acquiring enzymes. In June, the investment in microbial $\mathrm{C}$ acquisition was greater in the epilimnia compared to the hypolimnia (mean vector length 8.9 vs. $4.7, p=0.02)$. In July, however, this trend was no longer significant $(p=0.54)$, indicating distributed $\mathrm{C}$ acquisition of similar magnitude across lake strata in late summer.

\subsection{Relationships between water chemistry and enzyme activities in lake epilimnia}

Due to sampling constraints, DOC was measured in epilimnetic water only. There was a strong, linear increase in epilimnetic AP activity with increasing DOC concentration in June and July $\left(R^{2}=0.73\right.$ and 0.84 , respectively; $p$ values $<0.01$; Fig. 6). BG activity was not related to DOC in June or July. Likewise, the activities of the $\mathrm{N}$-acquiring enzymes, NAG + LAP, were unrelated to DOC in both seasons. None of the absolute EEAs were related to epilimnetic DIN : TP. When considered as enzyme ratios, epilimnetic investment in $\mathrm{C}: \mathrm{P}$ acquisition (BG: $\mathrm{AP}$ ) decreased with DOC concentration in June $\left(R^{2}=0.24, p=0.01\right)$ and was unrelated to DOC in July. $\mathrm{C}: \mathrm{N}$ acquisition (BG:NAG + LAP) was unrelated to DOC in both months.

The magnitude of epilimnetic microbial P limitation, described by vector angles, increased with rising DOC concentration in both months (June and July $R^{2}=0.67$ and 0.57 , respectively; $p$ values $<0.01$; Fig. 6 ). There were no relationships between vector angles and DIN : TP (data not shown). Likewise, there were no statistically significant relationships between vector length (i.e., C limitation) and water chemistry (data not shown).

\section{Discussion}

Our results reveal a pattern of microbial P limitation across these southwest Greenland Arctic lakes. Vector analysis indicated more severe P limitation in June compared to July, despite DIN : TP increasing in July. The overall pattern of $\mathrm{P}$ limitation of bacterioplankton and phytoplankton is consistent with previous research of plankton alkaline phosphatase activity in two lakes in the same study region, which also suggested P limitation of plankton communities (Brutemark et al., 2006). P limitation can be a factor that controls lake algal and microbial productivity and trophic status. In the high Canadian Arctic, for instance, $\mathrm{P}$ subsidies to lake and pond water caused increased microbial growth, indicating $\mathrm{P}$ as the primary limiting nutrient (Granéli et al., 2004). This was supported by another study completed across 20 lakes in Quebec, Canada, which demonstrated that TP, and not DOC, con- 

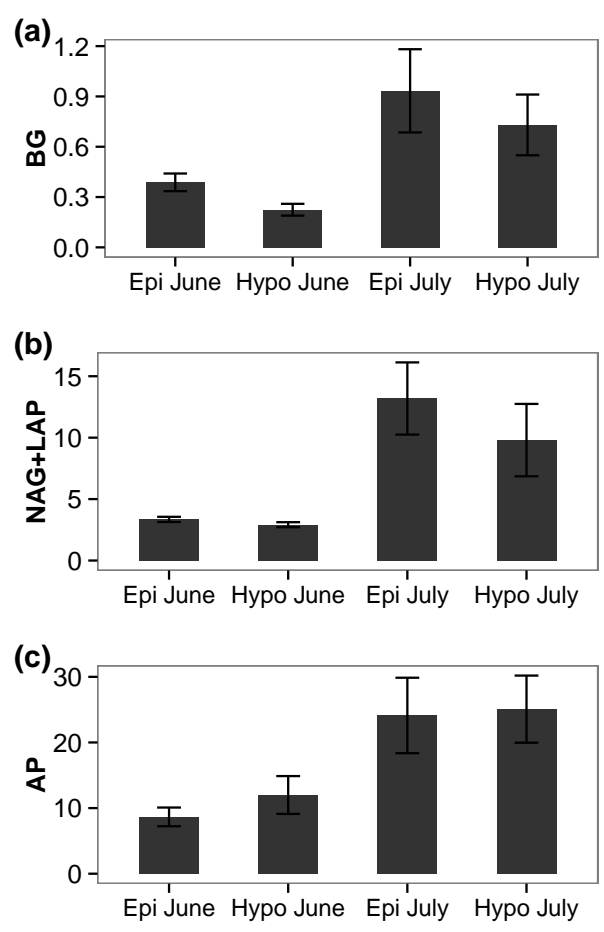

Figure 3. Absolute enzyme activities for (a) $\beta$-1,4-glucosidase (BG), (b) $\beta$-1,4-N-acetylglucosaminidase and leucine aminopeptidase (NAG + LAP), and (c) alkaline phosphatase (AP) across epilimnia and hypolimnia of study lakes, from June to July. Error bars are standard deviation. Units of activity are $\mu \mathrm{mol} \mathrm{mL} \mathrm{m}^{-1} \mathrm{~h}^{-1}$.
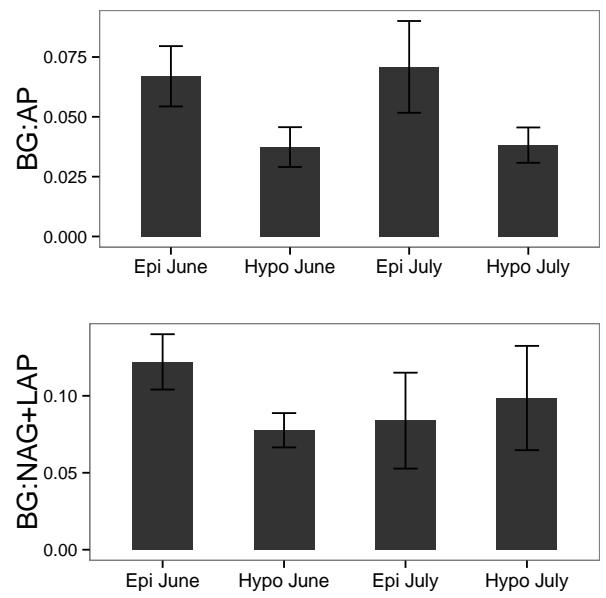

Figure 4. EEA ratios of BG relative to those of (a) NAG + LAP and (b) AP across lake strata for June and July. Error bars are standard deviation.

trolled microbial growth rates, respiration rates, and growth efficiency (Smith and Prairie, 2004). Further, P availability controlled the fate of DOC, such that in oligotrophic, low-P concentration environments DOC was mostly used for respiration (converted to $\mathrm{CO}_{2}$ ), rather than being incorporated into biomass.

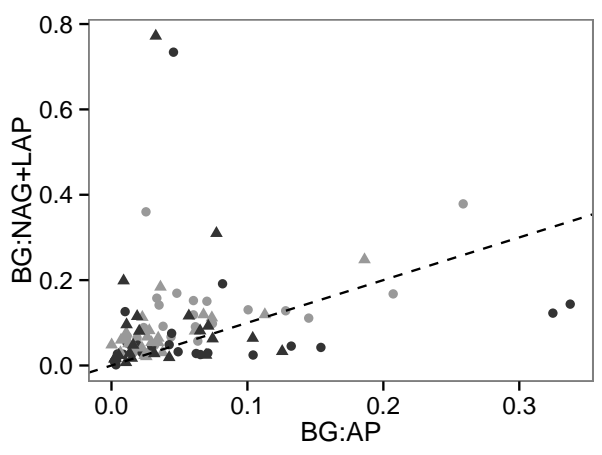

Figure 5. Scatterplot of microbial enzyme ratios (BG : NAG + LAP vs. BG : AP) about the $1: 1$ line. Included are $C: P$ and $C: N$ acquisition data of lake epilimnia (circles) and hypolimnia (triangles) from June (gray) to July (black). Dotted line indicates $1: 1\left(45^{\circ}\right)$ line. Vector angles (indicative of nutrient limitation) are calculated from these plotted data points, as deviation from the $1: 1$ line.

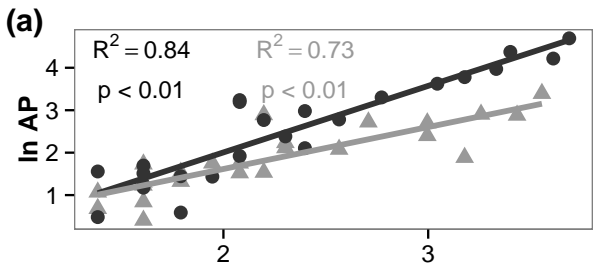

(b)

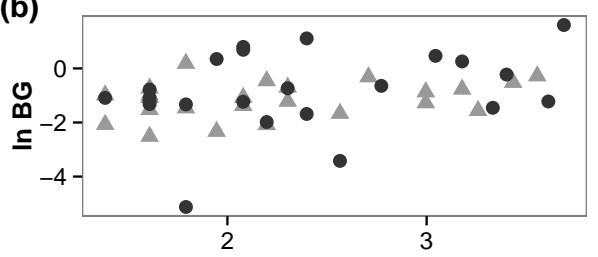

(c)

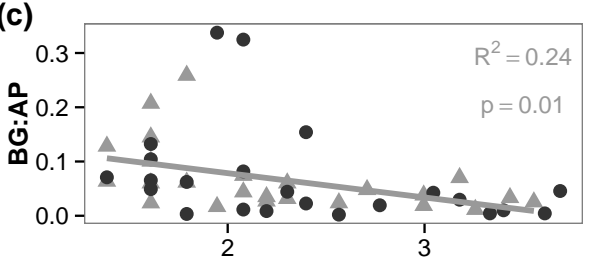

In DOC

Figure 6. Response of (a) AP, (b) BG, and (c) BG : AP to DOC in lake epilimnia. Data from June are indicated by gray triangles; data from July are indicated by black circles. Only significant relationships are displayed.

Various measures of enzyme activity indicated a positive relationship between $\mathrm{P}$ limitation and DOC, contrary to our expectation that DIN : TP might be a stronger predictor. Here, we quantitatively measured and reported it as DOC, but for discussion, DOM is a more appropriate term as it includes organic $\mathrm{N}$ and $\mathrm{P}$ as well as carbon. DOM is a broad group of organic compounds with varying lability depending on the source, chemical structure, and $\mathrm{N}$ and $\mathrm{P}$ content (Mineau 

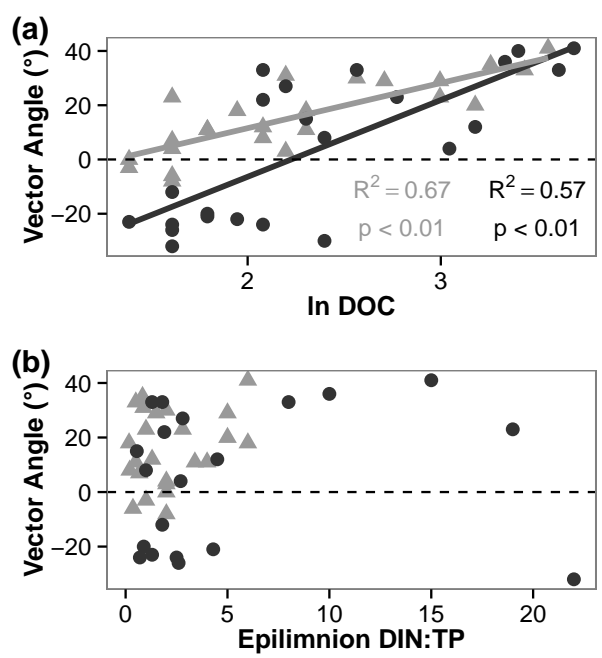

Figure 7. Vector angles in response to (a) DOC and (b) epilimnetic DIN : TP. Data from June are indicated by gray triangles; data from July are indicated by black circles. Dotted line indicates the boundary between $\mathrm{P}$ limitation (positive values) and $\mathrm{N}$ limitation (negative values). Only significant relationships are displayed.

et al., 2013; Parr et al., 2015). In these lakes, DOM positively co-varied with TN but had no relationship with TP. Collectively, these enzyme and water chemistry data suggest that the DOM in these lakes may provide a readily available source of N, while higher DOM concentrations are associated with enzyme-mediated microbial $\mathrm{P}$ acquisition.

DOM can contain distinct nutrient pools available for microbial consumption when conditions become stoichiometrically favorable. For instance, in a study of N-limited humic lakes in northern Sweden, DOM-associated $\mathrm{P}$ was used by bacterioplankton and phytoplankton when $\mathrm{N}$ was added into the experimental systems (Jansson et al., 2001). Furthermore, in the same study the authors showed that bacterioplankton production was strongly controlled by DOC, such that bacterioplanktonic production in water containing $15-20 \mathrm{mg} \mathrm{L}^{-1}$ of DOC could not be stimulated by further nutrient addition. However, DOM is not consistently a source of P in all lakes. Phosphorus amendments, in addition to simulated sunlight, were important in stimulating microbial degradation of DOC in an experiment using water from a southern Sweden humic lake, suggesting P limitation (Kragh et al., 2008). Another study of humic lakes located in southern Sweden demonstrated that $\mathrm{P}$ alone was not sufficient for stimulating microbial respiration and production; a source of labile $\mathrm{C}$ (glucose) was also required (Vidal et al., 2011). Together, these studies demonstrate that the interactions between bacteria and DOM are complex - DOM can either behave as a source of bioavailable material, providing bacteria with energy and certain nutrients, or remain a recalcitrant, unavailable pool of organic compounds.

DOM remained an important factor in determining microbial P demand and limitation from June to July, suggesting
DOM is the dominant source of nutrients available for microbial degradation and use. Lakes with low DOM appeared to have more seasonality of nutrient limitation than those with higher concentrations; as can be inferred from vector angles in Fig. 7a, only low-DOM lakes switched from $\mathrm{P}$ to $\mathrm{N}$ limitation in July, while higher-DOM lakes remained consistently P-limited. If the DOM pool is representative of $\mathrm{N}$ availability, it follows that $\mathrm{N}$ limitation would be more likely in low- than in high-DOM lakes. A seasonal shift in the type of DOM pool in low-DOM lakes could also be contributing to seasonal differences in DOM-related nutrient dynamics. Crump et al. (2003) investigated bacterioplankton community dynamics in relation to DOM in Toolik Lake, Alaska. In spring DOM was flushed from the landscape into an inlet stream and was labile due to extended soil and plant leaching, freeze-thaw processing, and microbial cell lysis. Moreover, this DOC was transported across the surface of the frozen tundra rather than the subsurface soils. The quality of this DOC then decreased as leaching of organic material decreased and the active layer deepened, allowing microbial degradation of DOM during transport.

In some areas of the Arctic, discharge-normalized DOC export to Arctic surface waters has decreased in recent decades (Striegl et al., 2005), with permafrost thaw and soil active-layer deepening contributing to this trend (Carey 2003; Kawahigashi et al., 2004; Striegl et al., 2005, 2007). If lake water DOM concentrations and quality are also declining, it is likely that nutrient subsidy and limitation patterns will also change. Our data suggest that lakes receiving less DOC may become less P-limited and move towards N limitation, since DOM is being suggested as an $\mathrm{N}$ source. Control of microbial production of enzymes and nutrient limitation may shift from organic matter to inorganic nutrients that are primarily flushed into the lakes during snowmelt and ice-off. Conversely, if DOC input into lakes were to increase due to increased terrestrial production within catchments, lakes would be predicted to become universally P-limited. Changes in nutrient sources and concentrations will affect microbial and autotrophic productivity (Smith and Prairie, 2004; Elser et al., 2007). It is likely that, as the amount of lake DOM changes, DOM composition and lability will shift as well. Bacterial community structure has been shown to change in correspondence with DOM quality in Arctic lakes, as some bacteria prefer more labile compounds while other species are adapted to utilizing recalcitrant forms (Crump et al., 2003). In this study, the seasonal source and quality of the DOM pool might have been inferred by the inclusion of oxidative enzymes, such as phenol oxidase and peroxidase, which are responsible for degrading terrestrially derived compounds such as phenols and aromatics, respectively (Sinsabaugh et al., 2008). Though BG is assumed to broadly represent $\mathrm{C}$ acquisition activity, oxidative enzyme activity may be an important metric in future studies.

Bacteria are of primary importance to freshwater ecosystems, as they transfer energy and nutrients often contained in 
organic matter to higher trophic levels (Azam et al., 1983), yet relatively little research on microbial ecology has been conducted in Arctic lakes. It is therefore important to consider microbial responses to factors that will be changing in the near future (such as active-layer depth and DOM concentrations) in order to understand ecological effects and directions of future change. We found that microbes in southwest Greenland lakes are generally P-limited and that the strength of microbial P limitation decreased by mid-summer. Further, DOM was very important in determining microbial nutrient demands and limitation due to its potential as an $\mathrm{N}$ source. Lakes within the permafrost landscape of this study region are likely to experience shifts in nutrient limitation patterns as aquatic-terrestrial linkages potentially weaken (due to active-layer increase) and DOM inputs decline. This study establishes current microbial nutrient limitation patterns that will allow us to assess response to future changes in this region.

\section{The Supplement related to this article is available online at doi:10.5194/bg-13-365-2016-supplement.}

Acknowledgements. Funding for this project was provided by the US National Science Foundation (grant no. 1203434) and the Dan \& Betty Churchill Fund. We thank Kathryn Warner; Emily Rice; Steve Juggins; our helicopter pilot, Alex Fürst; and the CPS staff for support in the field. We additionally thank Chris Osburn for DOC analysis, Corianne Tatariw and Sergio Velasco Ayuso for assistance with methods, and Johanna Cairns for assistance in figure rendering.

Edited by: W. F. Vincent

\section{References}

Anderson, N. J., Harriman, R., Ryves, D. B., and Patrick, S. T.: Dominant factors controlling variability in the ionic composition of West Greenland lakes, Arct. Antarct. Alp. Res., 33, 418-425, 2001.

Anisimov, O. and Reneva, S.: Permafrost and changing climate: the Russian perspective, Ambio, 35, 169-175, 2006.

APHA (American Public Health Association): Standard methods for the examination of water and wastewater, 20th edn. Washington, DC, USA, 2000.

Azam, F., Fenchel, T., Field, J. G., Gray, J. S., Meyer-Reil, L. A., and Thingstad, F.: The ecological role of water-column microbes in the sea, Mar. Ecol.-Prog. Ser., 10, 257-263, 1983.

Bergström, A. K.: The use of TN : TP and DIN : TP ratios as indicators for phytoplankton nutrient limitation in oligotrophic lakes affected by N deposition, Aquat. Sci., 72, 277-281, 2010.

Blunden, J. and Arndt, D. S.: State of the Climate in 2013, B. Am. Meteorol. Soc., 95, S1-S279, 2014.

Brutemark, A., Rengefors, K., and Anderson, N. J.: An experimental investigation of phytoplankton nutrient limitation in two contrasting low arctic lakes, Polar Biol., 29, 487-494, 2006.
Carey, S. K.: Dissolved organic carbon fluxes in a discontinuous permafrost subarctic alpine catchment, Permafrost Periglac., 14, 161-171, 2003.

Christiansen, H. H., Etzelmüller, B., Isaksen, K., Juliussen, H., Farbrot, H., Humlum, O., Johansson, M., Ingeman-Nielsen, T., Kristensen, L., Hjort, J., Holmlund, P., Sannel, A. B. K., Sigsgaard, C., Akerman, H. J., Foged, N., Blikra, L. H., Pernosky, M. A., and Ødegård, R. S.: The thermal state of permafrost in the Nordic Area during the international polar year 2007-2009, Permafrost Periglac., 21, 156-181, 2010.

Clinton, S. M., Edwards R. T., and Findlay S. E. G.: Exoenzyme activities as indicators of dissolved organic matter composition in the hyporheic zone of a floodplain river, Freshwater Biol., 55, 1603-1615, 2010.

Cotner, J. B. and Biddanda, B. A.: Small players, large role: microbial influence on biogeochemical processes in pelagic aquatic ecosystems, Ecosystems, 5, 105-121, 2002.

Crump, B. C., Kling, G. W., Bahr, M., and Hobbie, J. E.: Bacterioplankton community shifts in an arctic lake correlate with seasonal changes in organic matter source, Appl. Environ. Microb., 69, 2253-2268, 2003.

del Giorgio, P. A. and Cole, J. J.: Bacterial growth efficiency in natural aquatic systems, Annu. Rev. Ecol. Syst., 29, 503-541, 1998.

Elser, J. J., Bracken, M. E., Cleland, E. E., Gruner, D. S., Harpole, W. S., Hillebrand, H., Ngai, J. T., Seabloom, E. W., Shurin, J. B., and Smith, J. E.: Global analysis of nitrogen and phosphorus limitation of primary producers in freshwater, marine and terrestrial ecosystems, Ecol. Lett., 10, 1135-1142, 2007.

Findlay, S. E., Sinsabaugh, R. L., Sobczak, W. V., and Hoostal, M.: Metabolic and structural response of hyporheic microbial communities to variations in supply of dissolved organic matter, Limnol. Oceanogr., 48, 1608-1617, 2003.

Freimann, R., Bürgmann, H., Findlay, S. E., and Robinson, C. T.: Response of lotic microbial communities to altered water source and nutritional state in a glaciated alpine floodplain, Limnol. Oceanogr., 58, 951-965, 2013.

Frey, K. E. and McClelland, J. W.: Impacts of permafrost degradation on arctic river biogeochemistry, Hydrol. Process., 23, 169182, 2009.

Frey, K. E. and Smith, L. C.: Amplified carbon release from vast West Siberian peatlands by 2100 , Geophys. Res. Lett., 32, 1-4, 2005.

German, D. P., Weintraub, M. N., Grandy, A. S., Lauber, C. L., Rinkes, Z. L., and Allison, S. D.: Optimization of hydrolytic and oxidative enzyme methods for ecosystem studies, Soil Biol. Biochem., 43, 1387-1397, 2011.

Granéli, W., Bertilsson, S., and Philibert, A.: Phosphorus limitation of bacterial growth in high Arctic lakes and ponds, Aquat. Sci., 66, 430-439, 2004.

Hanna, E., Mernild, S. H., Cappelen, J., and Steffen, K.: Recent warming in Greenland in a long-term instrumental (1881-2012) climatic context: I. Evaluation of surface air temperature records, Environ. Res. Lett., 7, 1-15, 2012.

Harper, J., Hubbard, A., and Ruskeeniemi, T.: The Greenland analogue project, yearly report 2010, Swedish Nuclear Fuel and Waste Management Co., Stockholm, Sweden, 2011.

Hill, B. H., Elonen, C. M., Jicha, T. M., Kolka, R. K., Lehto, L. L., Sebestyen, S. D., and Seifert-Monson, L. R.: Ecoenzymatic stoi- 
chiometry and microbial processing of organic matter in northern bogs and fens reveals a common P-limitation between peatland types, Biogeochemistry, 120, 203-224, 2014.

Hinkel, K. M. and Nelson F. E.: Spatial and temporal patterns of active layer thickness at Circumpolar Active Layer Monitoring (CALM) sites in northern Alaska, 1995-2000, J. Geophys. Res.Atmos., 108, 1-13, 2003.

Hinzman, L. D., Kane, D. L., Gieck, R. E., and Everett, K. R.: Hydrologic and thermal properties of the active layer in the Alaskan Arctic, Cold Reg. Sci. Technol., 19, 95-110, 1991.

Hobbie, J. E., Peterson, B. J., Bettez, N., Deegan, L., O’Brien, W. J., Kling, G. W., Kipphut, G. W., Bowden, W. B., and Hershey, A. E.: Impact of global change on the biogeochemistry and ecology of an Arctic freshwater system, Polar Res., 18, 207-214, 1999.

Hobbie, J. E., Bahr, M., Bettez, N., and Rublee, P. A.: Microbial food webs in oligotrophic arctic lakes, in: Microbial Biosystems: New Frontiers, Proceedings of the 8th International Symposium on Microbial Ecology, Atlantic Canada Society for Microbial Ecology, Halifax, Canada, 293-298, 2000.

Jansson, M., Bergström, A. K., Drakare, S., and Blomqvist, P.: Nutrient limitation of bacterioplankton and phytoplankton in humic lakes in northern Sweden, Freshwater Biol., 46, 653-666, 2001.

Jorgenson, M. T., Racine, C. H., Walters, J. C., and Osterkamp, T. E.: Permafrost degradation and ecological changes associated with a warming climate in central Alaska, Climatic Change, 48, 551-579, 2001.

Jorgenson, M. T., Shur, Y. L., and Pullman, E. R.: Abrupt increase in permafrost degradation in Arctic Alaska, Geophys. Res. Lett., 33, 1-4, 2006.

Jorgenson, M. T., Romanovsky, V., Harden, J., Shur, Y., O’Donnell, J., Schuur, E. A. G., Kanevskiy, M., and Marchenko, S.: Resilience and vulnerability of permafrost to climate change, Can. J. Forest Res., 40, 1219-1236, 2010.

Kawahigashi, M., Kaiser, K., Kalbitz, K., Rodionov, A., and Guggenberger, G.: Dissolved organic matter in small streams along a gradient from discontinuous to continuous permafrost, Glob. Change Biol., 10, 1576-1586, 2004.

Kling, G. W., Kipphut, G. W., and Miller, M. C.: The flux of CO2 and $\mathrm{CH} 4$ from lakes and rivers in arctic Alaska, Hydrobiologia, 240, 23-36, 1992.

Kragh, T., Søndergaard, M., and Tranvik, L.: Effect of exposure to sunlight and phosphorus-limitation on bacterial degradation of coloured dissolved organic matter (CDOM) in freshwater, FEMS Microbiol. Ecol., 64, 230-239, 2008.

Lawrence, D. M. and Slater, A. G.: A projection of severe nearsurface permafrost degradation during the 21 st century, Geophys. Res. Lett., 32, 1-5, 2005.

Levine, M. A. and Whalen, S. C.: Nutrient limitation of phytoplankton production in Alaskan Arctic foothill lakes, Hydrobiologia, 455, 189-201, 2001.

Ljungdahl, L. G. and Eriksson, K.-E.: Ecology of microbial cellulose degradation, Adv. Microb. Ecol., 8, 237-299, 1985.

McClelland, J. W., Stieglitz, M., Pan, F., Holmes, R. M., and Peterson, B. J.: Recent changes in nitrate and dissolved organic carbon export from the upper Kuparuk River, North Slope, Alaska, J. Geophys. Res., 112, 1-13, 2007.

Mayewski, P. A., Sneed, S. B., Birkel, S. D., Kurbatov, A. V., and Maasch, K. A.: Holocene warming marked by abrupt onset of longer summers and reduced storm frequency around Greenland, J. Quaternary Sci., 29, 99-104, 2014.

Mineau, M. M., Rigsby, C. M., Ely, D. T., Fernandez, I. J., Norton, S. A., Ohno, T, Valett, H. M., and Simon, K. S.: Chronic catchment nitrogen enrichment and stoichiometric constraints on the bioavailability of dissolved organic matter from leaf leachate, Freshwater Biol., 58, 248-260, 2013.

Moorhead, D. L., Rinkes, Z. L., Sinsabaugh, R. L., and Weintraub, M. N.: Dynamic relationships between microbial biomass, respiration, inorganic nutrients and enzyme activities: informing enzyme-based decomposition models, Front. Microbiol., 4, 112, 2013.

Nielsen, A. B.: Present conditions in Greenland and the Kangerlussuaq area, Working Report 2010-07, Geological Survey of Denmark and Greenland, POSIVA, Eurajoki, Finland, 2010.

Parr, T. B., Cronan, C. S., Ohno, T., Findlay, S. E., Smith, S., and Simon, K. S.: Urbanization changes the composition and bioavailability of dissolved organic matter in headwater streams, Limnol. Oceanogr., 60, 885-900, 2015.

Perren, B. B., Douglas, M. S., and Anderson, N. J.: Diatoms reveal complex spatial and temporal patterns of recent limnological change in West Greenland, J. Paleolimnol., 42, 233-247, 2009.

Romanovsky, V. E., Sazonova T. S., Balobaev V. T., Shender N. I., and Sergueev D. O.: Past and recent changes in air and permafrost temperatures in eastern Siberia, Global Planet. Change, 56, 399-413, 2007.

Schuur, E. A., Bockheim, J., Canadell, J. G., Euskirchen, E., Field, C. B., Goryachkin, S. V., Hagemann, S., Kuhry, P., Lafleur, P. M., Lee, H., Mazhitova, G., Nelson, F. E., Rinke, A., Romanovsky, V. E., Shiklomanov, N., Tarnocai, C., Venevsky, S., Vogel, J. G., and Zimov, S. A.: Vulnerability of permafrost carbon to climate change: Implications for the global carbon cycle, BioScience, 58, 701-714, 2008.

Simon, K. S., Simon, M. A., and Benfield, E. F. Variation in ecosystem function in Appalachian streams along an acidity gradient, Ecol. Appl., 19, 1147-1160, 2009.

Sinsabaugh, R. L. and Foreman, C. M.: Activity profiles of bacterioplankton in a eutrophic river, Freshwater Biol., 46, 1239-1249, 2001.

Sinsabaugh, R. L., Lauber, C. L., Weintraub, M. N., Ahmed, B., Allison, S. D., Crenshaw, C., Contosta, A. R., Cusack, D., Frey, S., Gallo, M. E., Gartner, T. B., Hobbie, S. E., Holland, K., Keeler, B. L., Powers, J. S., Stursova, M., Takacs-Vesbach, C., Waldrop, M. P., Wallenstein, M. D., Zak, D. R., and Zeglin, L. H.: Stoichiometry of soil enzyme activity at global scale, Ecol. Lett., 11, 1252-1264, 2008.

Sinsabaugh, R. L., Hill, B. H., and Shah, J. J. F.: Ecoenzymatic stoichiometry of microbial organic nutrient acquisition in soil and sediment, Nature, 462, 795-798, 2009.

Smith, E. M. and Prairie, Y. T.: Bacterial metabolism and growth efficiency in lakes: the importance of phosphorus availability, Limnol. Oceanogr., 49, 137-147, 2004.

Stendel, M. and Christensen, J. H.: Impact of global warming on permafrost conditions in a coupled GCM, Geophys. Res. Lett., 29, 1-4, 2002.

Striegl, R. G., Aiken, G. R., Dornblaser, M. M., Raymond, P. A., and Wickland, K. P.: A decrease in discharge-normalized DOC export by the Yukon River during summer through autumn, Geophys. Res. Lett., 32, 1-4, 2005. 
Striegl, R. G., Dornblaser, M. M., Aiken, G. R., Wickland, K. P., and Raymond, P. A.: Carbon export and cycling by the Yukon, Tanana, and Porcupine rivers, Alaska, 2001-2005, Water Resour. Res., 43, 1-9, 2007.

Turner, B. L., McKelvie, I. D., and Haygarth, P. M.: Characterization of water extractable soil organic phosphorus by phosphatase hydrolysis, Soil Biol. Biochem., 34, 27-35, 2002.

Vidal, L. O., Granéli, W., Daniel, C. B., Heiberg, L., and Roland, F.: Carbon and phosphorus regulating bacterial metabolism in oligotrophic boreal lakes, J. Plankton Res., 33, 1747-1756, 2011.

Villar-Argaiz, M., Medina-Sánchez, J. M., and Carrillo, P.: Microbial plankton response to contrasting climatic conditions: insights from community structure, productivity and fraction stoichiometry, Aquat. Microb. Ecol., 29, 253-266, 2002.

Waelbroeck, C., Monfray, P., Oechel, W. C., Hastings, S., and Vourlitis, G.: The impact of permafrost thawing on the carbon dynamics of tundra, Geophys. Res. Lett., 24, 229-232, 1997.

Whalen, S. C. and Cornwell, J. C.: Nitrogen, phosphorus, and organic carbon cycling in an arctic lake, Can. J. Fish. Aquat. Sci., 42, 797-808, 1985.
White, D., Hinzman, L., Alessa, L., Cassano, J., Chambers, M., Falkner, K., Francis, J., Gutowski Jr., W. J., Holland, M., Holmes, R. M., Huntington, H., Kane, D., Kliskey, A., Lee, C., McClelland, J., Peterson, B., Rupp, T. S., Straneo, F., Steele, M., Woodgate, R., Yang, D., Yoshikawa, K., and Zhang, T.: The arctic freshwater system: Changes and impacts, J. Geophys. Res., 112, 1-21, 2007.

Zhang, T., Frauenfeld, O. W., Serreze, M. C., Etringer, A., Oelke, C., McCreight, J., Barry, R. G., Gilichinsky, D., Yang, D., Ye, H., Ling, F., and Chudinova S.: Spatial and temporal variability in active layer thickness over the Russian Arctic drainage basin, J. Geophys. Res., 110, 1-14, 2005.

Zhang, Y., Chen, W., and Riseborough, D. W.: Transient projections of permafrost distribution in Canada during the 21 st century under scenarios of climate change, Global Planet. Change, 60, 443456, 2008. 